\title{
A Z generáció utazási szokásai
}

\section{Travel habits of generation Z}

\section{ÖSSZEFOGLALÍ́S:}

Bevezetés: A turisztikai iparág egy fontos terület, mely hozzájárul az emberek rekreációjához, és egyben igen sok ország számára gazdasági potenciállal is bír. A COVID-járvány érzékenyen érintette ezt a szektort, melynek gazdasági hatása az utazásszervezőket sem kerülte el. Az utazási irodák létét és forgalmát a jövőben igen erőteljesen befolyásolja az, hogy a Z generációt meg tudja-e szólítani az általa kínált szolgáltatásokkal.

Célkitűzés: A hazai $Z$ generáció utazási motivációinak és szokásainak a vizsgálata.

Eredmények: A kitöltők 26,3\%-a nyilatkozta, hogy szokott utazási irodával utazni. A válaszadók $10 \%$-a egyáltalán nem vesz igénybe utazási irodai szolgáltatást. A válaszadók többsége azonban igénybe vesz valamilyen szolgáltatást, melyek közül a szállásfoglalás (22,5\%), a packagek (22,5\%) és az utasbiztosítás $(22,1 \%)$ voltak a legnépszerübbek. A Z generáció fontosnak véli az utazási irodákat, ahol az utazási tanácsadó szerepe felértékelődik. Leginkább akkor vennék igénybe az utazási irodák szolgáltatásait, ha távolabbi desztinációt választanak és amenynyiben kedvező az ár, vagy ha bonyolultabb a foglalási módszer.

Következtetések: A Z generáció egyelőre elutasítja a hagyományos, szervezett utazási formákat. A kutatás eredménye szerint csak legvégső esetben vennék igénybe a hagyományos utazási csomagokat, melyeknél az ár-érték arány igen fontos a vásárlási döntésben.

Kulcsszavak: Z generáció, utazási szokások, utazási irodák szolgáltatásai.

\section{BEVEZTÉS}

„A turizmus jelenlegi dimenzióiban viszonylag új jelenség, bár a szabadidőben, nem a mindennapi életvitelhez kapcsolódóan történő utazások az ókortól kezdődően ismertek voltak" (Puczkó Rátz, 2011, 56. o.). A középkorban is megfigyelhető turisztikai tevékenység, hiszen a zarándoklatok, melyeknek célja a vallási emlékhelyek felkeresése, vagy az arisztokrácia kiváltságaként megjelenő utazások (Pernyéz, 2003) ezt igazolják.

Az újkor nagy változást hozott, és a turisztikai kereslet fellendülését eredményezte az emberek diszkrecionális jövedelmének növekedése. A 19. században a tengerparti üdülések dominanciáját felváltotta az aktivitás és élménykeresés. A 20. szá-

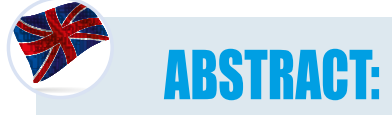

Introduction: The tourism industry is an important area that contributes to the recreation of people while also maintaining economic potential for many countries. The COVID epidemic has affected the sector significantly, the economic impact of which has not unaffected the tour operators either. In the future, the existence and turnover of travel agencies will be highly influenced by their ability to address the Z-generation with their service offers.

Aim: Examination of the travel motivations and habits of the Hungarian $Z$ generation.

Results: $26.3 \%$ of the respondents stated that they have used travel agency for their travels. While $10 \%$ of the respondents answered that they do not use any travel agency services at all. However, the majority of the respondents use some kind of service, of which hotel reservation $(22.5 \%)$, packages $(22.5 \%)$ and travel insurance (22.1\%) were the most popular. Generation Z considers travel agencies important, where the role of the travel consultant is becoming increasingly significant. They would mostly use the services of travel agencies if they choose a more distant destination and if the price is favorable, or if the booking method is more complicated.

Conclusions: Generation Z currently rejects traditional, organized forms of travel. According to the results of the research, traditional travel packages are used only as a last resort, where value for money is very important in the purchase decision.

Keyworlds: Generation Z, travel habits, travel agency services

zadi társadalmi, gazdasági és infokommunikációs fejlődéssel párhuzamosan a mai értelemben használt turizmus megjelent.

Ez a települési szolgáltatásokra nagy hatással volt (Bujdosó, 2004). Napjainkra nagyot változott a világ, és ezzel együtt változtak a turisztikai motivációk, az utazási szokások, a foglalási és információszerzési szokások egyaránt. A változásokat a turisztikai iparág kínálati elemeinek változása is követte, valamint a marketingkommunikációs üzenetek és ezeket közvetítő eszközök egyaránt.

A napjaink modern turizmusa egy globális társadalmi jelenségként is értelmezhető, amelyben a szabadidő hasznos és tartalmas eltöltése megjelenik, vagy a rekreáció egyik legkedveltebb formájává válik a turizmus, mely egyben az életminőség

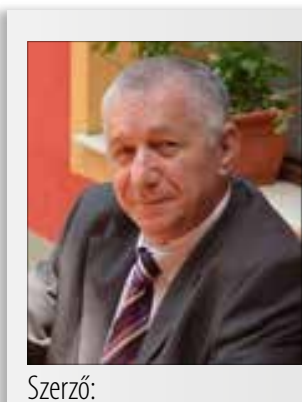

TÜTÜNKOV-HRISZTOV JORDÁN

föiskolai adjunktus Budapesti Metropolitan Egyetem htutunkov@metropolitan.hu Tudományos tevékenysége: $\mathrm{mtmt}$

Főbb kutatási területei: közvetítő szektor

További szerzők: SZABÓ KATALIN

szabokata0905@gmail.com

KINCZEL ANTONIA

antokincz@gmail.com

MOLNÁR ANIKÓ miller.e.annie@gmail.com

BUJDOSÓ ZOLTÁN

Bujdoso.Zoltan@szie.hu

MÜLLER ANETTA

muller.anetta@econ.unideb.hu 
meghatározó eleme (Sőrés 2013), hangsúlyos gazdasági ágazat (Mundruczóné et al., 2010).

A Horwath HTL trendkutatása szerint a jövőben az egyik legfontosabb és legmeghatározóbb szegmens lesz az Y és a $Z$ generáció, habár a számukat tekintve nem a legnagobb fogyasztói csoport (Tourism-Mega-Trends). A szolgáltatóknak így tehát már nem csupán az Y generáció, hanem a $\mathrm{Z}$ generáció igényeit is meg kell ismerni és ki kell elégíteni, melyben az élményelemek dominánsan felerősödnek (Grotte Kulcsár 2018). JUNVI 2015-ben megjelent tanulmánya a generációk számát is ismerteti, mely szerint az Y generációhoz 86 millióan tartoztak, melynek 200 milliárd dolláros vásárlóerôt tulajdonított, és a szállodaipar egyik legjövedelmezőbb szegmensének tekintették. A Z generáció igaz, hogy fiatal, de a családok vásárlási döntéseit nagymértékben befolyásolják, ami több mint 600 milliárd dollárt eredményezhet. Heti rendszerességgel 16,90 dollár zsebpénzt kapnak szüleiktől, ami évi 44 milliárd dollárt jelent. A Z generáció 2020-ra és utána a világ vásárlóinak 40\%-át jelentheti. A Z generáció az Y generációt le is hagyhatja váráslóerőben, mintegy évi 3 milliárd dollárral (Donovan, 2017).

Az Y generációra jellemző az, hogy mindent elektronikusan intéz: a szálláshely- vagy repülőjegy-foglaláson keresztül a számlák teljesítéséig. Erdeiné - Gally (2015) szerzőpáros szerint a digitális korszakban például egy „elektronikus piactér” nem csak kereslet és kínálat találkozásának helyszíne, de egyfajta „tudásbázis”-ként is értelmezhető. Utazási döntések meghozatala előtt az elektronikus online felületről szereznek információt elsődlegesen. A Z generáció (1995-2010 között születettek) szokásait felmérő kutatások megállapították, hogy a Digitális Generáció még rohanóbb életet él, mint az Y generáció, melynek történéseit online felületeken a nyilvánossággal is rendszeresen megosztják (Pál - Törőcsik, 2013).

\section{MÓDSTEREK}

Tanulmányunk célja a hazai $Z$ generáció utazási motivációinak és szokásainak a vizsgálata: Ennek érdekében komplex, kvalitatív és kvantitatív módszereket is tartalmazó primer kutatást végeztünk. A szakmai mélyinterjúk mellett online kérdőíves felmérést végeztünk a Budapesti Metropolitan Egyetem Turizmus-vendéglátás alapszakos nappalis hallgatók körében. rés a $\mathrm{Z}$ generációt képviselő hallgatókon tesztelte az utaztatási szektorral kapcsolatos általános felfogást, a kérdőívet 133-an töltötték ki anonim módon. A minta nagysága nem számít reprezentatívnak, de mivel magát a $\mathrm{Z}$ generációt kérdeztük meg, a kapott válaszok jól értékelhetők.

Szekunder kutatás keretében a Travelport és Amadeus GDS rendszerek jeles magyarországi képviselőivel készült szakmai interjút is vizsgáltuk, amely szintén lényeges jövóképet mutat a Z generációnak a szervezett turizmussal kapcsolatos hozzáállásáról (Tóth, 2020).

\section{EREDMÉNYEK}

A Z generációt képviselő minta átlagéletkora 24,6 év ( $s d=3,2)$, melyben a nők és férfiak aránya közel azonos volt.

Az utazási szokásokat és utazási motivációkat vizsgáló kérdések közül az utazási irodák igénybevételét vizsgáltuk. A kitöltők válaszai arra, hogy szoktak-e utazási irodával utazni, 36,8\%-a (49 fó) nem szokott utazási irodával utazni, 26,3\%-uk (35 fó) azt nyilatkozta, hogy igénybe veszi az utazási iroda szolgáltatásait, 36,8\%-uk (49fó) pedig gyermekként utazott a szüleivel együtt utazási irodán keresztül.

Rákérdeztünk arra, hogy mi az oka annak, hogy nem szoktak az utazási irodával utazni. Az emberek 30,1\%-a (4o fó) magának szereti megszervezni az utazását, interneten keresztül, emiatt nem választ az utazási iroda lehetőségeiból. 15,8\%-uk (21 fó) ritkán szokott utazni, szintén 15,8\%-uknak (21 fó) pedig mások szokták megszervezni az utazásaikat. 14,3\%-nak (19fó) eddig nem volt szüksége arra, hogy utazási irodához forduljon. 24,1\%-uk (32 fó) pedig egyéb okok miatt nem szokott az utazási irodával utazni.
A tíz kérdésból álló kérdőíves felmé-

A legtöbben az utazási irodák szolgáltatásaiból a szállásfoglalást (61 fó, 22,5\%) és az utazási csomagot veszik igénybe (61 fó, 22,5\%). Szintén gyakori említést kapott az utasbiztosítás (6ofó, 22,1\%) és a repülőjegy-vásárlás szolgáltatás is (43 fó, 15,9\%). A kevésbé igénybe vett szolgáltatások közé sorolható a valutaváltás, hiszen csupán 16 fó, 5,9\% élt ezzel a lehetőséggel. Bár a kitöltők 36,8\%-a (49 fó) nem szokott utazási irodával utazni, kutatásunk azt bizonyítja, hogy ezek közül az emberek közül is egy részük igénybe vesz valamilyen szolgáltatást, hiszen a kitöltók 10,00\%-a (27 fó) válaszolta azt, hogy egyik szolgáltatást sem vette eddig igénybe. A kitöltóknek a 3\%-a egyéb szolgáltatásokat vett eddig igénybe.

A kutatásunkban 1-5-ös skálán értékelhették a válaszadók, hogy szerintük mennyire van szükség a hagyományos utazási irodákra (1.ábra). Az eredmény azt bizonyítja, hogy szükség van rájuk (átlag=3,66, sd=0,85). Kíváncsiak voltunk a szükségességük megítélése mögött húzódó okokra is. A legmagasabb átlagértéket az egyéb kategória után (átlag=6,2, sd=1,75) az utazási iroda kedvező árai kapta (átlag=4,91, $s d=1,53)$. Szintén magas átlagértékkel bír az utazási tanácsadó szerepe (át$\operatorname{lag}=4,78, s d=1,41$ ), hiszen ismeri a vevő preferenciáit és ez a személy megbízik benne. Fontos szempontnak tartják az emberek azt, hogy az utazási irodák megfelelő szakmai kompetenciával rendelkeznek (átlag=3,26, $s d=1,47$ ), felelősséget vállalnak a szolgáltatásokért (átlag=3,02, $s d=1,81$ ), ugyanakkor szerintük ismeretlen desztinációk esetében biztonságosabb velük utazni (átlag=2,92, sd=1,67). A legkisebb átlagértéket a kényelem kapta (át$l a g=2,9, s d=1,58$ ). (1. ábra)

A turisztikai szolgáltatók arra törekszenek, hogy olyan élményajánlatokat

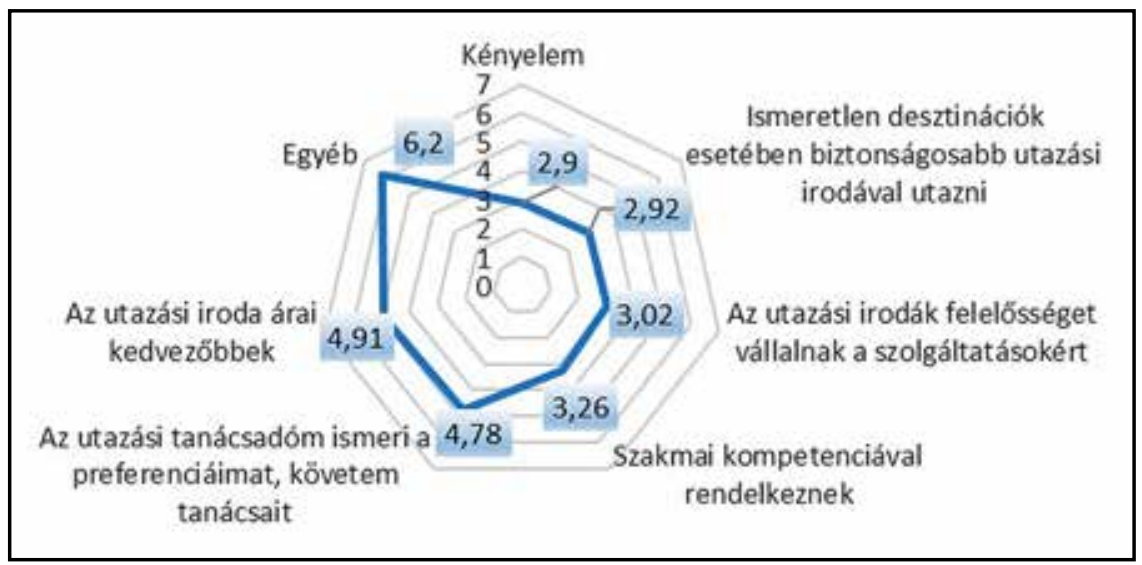

1. ábra: Az utazási irodák szükségességének megítélése a $Z$ generáció válaszai alapján (1-5 likert skálás, 1= egyáltalán nem fontos, 5= teljes mértékben fontos) 
biztosítsanak a turistáknak, melyeknél az egyediség, a különlegesség fontos momentum, ugyanakkor a sokszínú programok, szolgáltatások a felhasználók igényeihez igazodjanak (Michalkó, 2011).

A turisztikai kereslet és a turisztikai trend állandóan változik, melyhez a kínálatnak is igazodnia kell.

Arra a kérdésre, hogy mikor vennének igénybe utazási irodát, több választ is jelölhettek kitöltőink (2. ábra). 28,3\%-uk (7o fó) távolabbi utazáshoz venné igénybe az utazási irodát. Fontos szerepet játszanak az árak, 25,5\%-uk (63fö) üdülésnél, ha az árak megfelelőek, akkor szívesen élnének az utazási iroda által felkínált lehetőségekkel. Ha bonyolultabb a foglalás menete, összetettebb repülőjegyek vásárlásakor a kényelmesebb, rövidebb utat választanák az emberek, így ilyen esetekben gyakran fordulnának az utazási irodákhoz (23,5\%, 58 fó). Külföldi szállásfoglaltatásnál is, 17,8\%-uk (44 fó) választaná az utazási irodát. 4,9\%-a a kitöltőknek (12 fó) soha nem venné igénybe az utazási irodát, mivel ők saját maguknak szervezik meg az útjaikat. (2. ábra)

A válaszadók szerint a legnagyobb veszélyt az utazási irodákra a globalizáció jelenti, hiszen erre az átlagérték=3,64, sd=1,15. Rengeteget olvashattunk és hallhattunk a migránsválságról, ami befolyásolja az utazási irodák veszélyeit is az emberek szerint (átlagérték=3,42, $s d=1,46$ ). A mai modern világban minden változik, emiatt veszélyként sorolható az utazási szokások változása is (átlagérték=3,17, $s d=1,29)$. Az anyagi háttér nagyon fontos szerepet játszik abba, hogy igénybe vesszük-e az utazási irodát, emiatt egy pénzügyi váltság veszélyt jelentene az utazási irodákra (átlagérték=2,62, $s d=1,19)$. Az internetet értékelték a válaszadók a legkisebb veszélynek (átlagérték=2,15, sd=1,42).

\section{Irodalomjegyzék}

Bujdosó, Z (2004): A megyehatár hatása a városok vonzáskörzetére Hajdú-Bihar megye példáján. PhD értekezés, Debreceni Egyetem, $221 \mathrm{p}$.

Donovan, L. (2017): Purchasingpower of generation $Z$. http://www.business2community.com/ consumer-marketing/purchasing-power-generation-z-01926562. Letöltve: 2020. október 4.

Erdeiné, Késmárki - Gally, Sz. (2015): Application of a modern marketplace in the European agribusiness. Agroeconomia Croatica. 5(1). pp. 41-50.

Grotte, J - Kulcsár, N. (2018): Szállodai élmény elvárások az Y és Z generáció esetében [Defining hotel experience in case of the $Y$ and $Z$ generation]. In: Csapó, János; Gerdesics, Viktória; Törőcsik, M. (szerk.) Generációk a turizmusban. I. Nemzetközi Turizmusmarketing Konferencia: Tanulmánykötet. Pécs, Magyarország: Pécsi

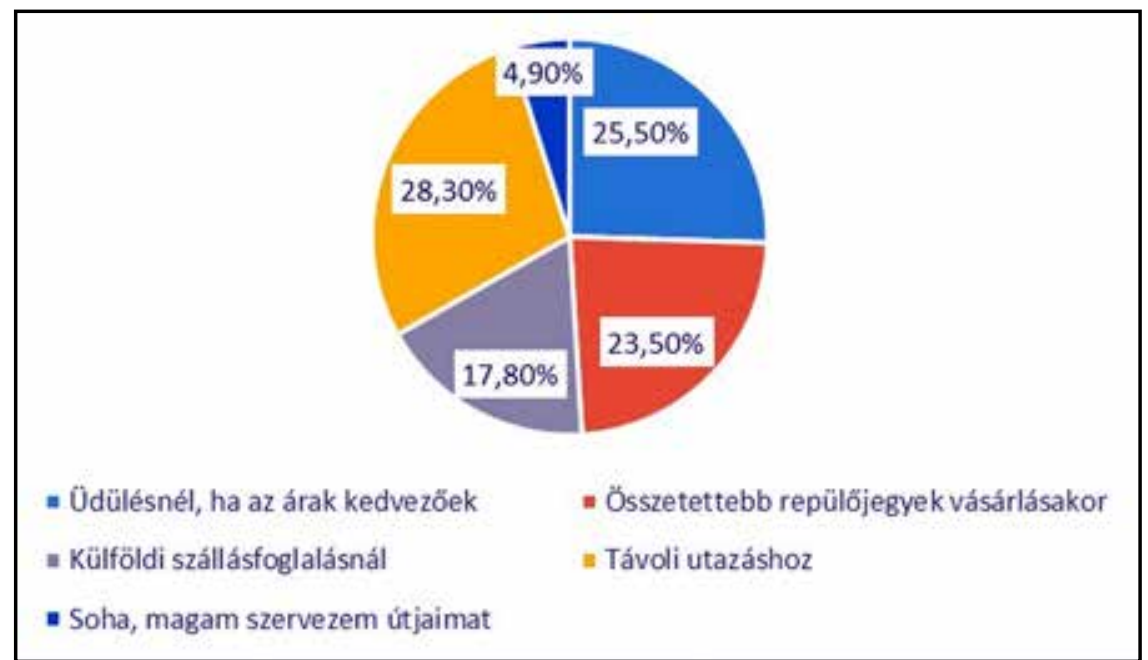

\section{2. ábra: Az utazási irodák szolgáltatásainak igénybevételét befolyásoló tényezők}

\section{KÖVETKEZTETÉSEK}

Fontos figyelmeztetés a hagyományos utaztatási szektornak, hogy a Z generáció - a világ első globális és digitális nemzedéke - egyelőre elutasítja a hagyományos, szervezett utazási formákat. Az empirikus kutatás eredménye szerint csak legvégső esetben vennék igénybe a hagyományos utazási csomagokat. Amennyiben az utazási irodai szektor nem nyit irányukba, nem tanul meg a nyelvükön kommunikálni, úgy egy évtizeden belül az utazási irodai szektor csak a középkorú és idősebb utasokra számíthat (Tütünkov, 2018).

A hagyományos utazási irodáknak fel kell gyorsítaniuk a digitális átalakulásukat, ha nem akarnak lemaradni a Z generáció megnyeréséért folytatott versenyben. Változtatni kell az utazási irodai marketingen: az élményt, desztinációt, hangulatot kellene reklámozni, nem az árakat. Ott kell lenni a közösségi oldalakon, appokat kell létrehozni. A jövőben is szükség lesz utazási irodai szakemberekre, mert a turisztikai szolgáltatásokat is emberek állítják majd elő, „a chatrobot meg tudja mondani, hogy Párizsban át kell szállni, de egy utazási irodai szakember megmondja azt is, hogy nem fogsz átérni 40 perc alatt az egyik repülőtérról a másikra" (Tóth, 2020, 56-57. o.).

A turisztikai szakemberek egybehangzó véleménye szerint a koronavírus-járványt követő időkben megváltoznak az emberek utazási szokásai. Külföldi utazásokkal szemben előtérbe kerülnek a belföldi utazások, a repülögépes közlekedést felváltja a személygépkocsival való utazás. A jövőben nagyobb hangsúlyt kap a biztonságos utazás, és ezért az utasok figyelme újból az utazási irodák felé fordul, akik szükség esetén segítséget tudnak nyújtani utasaiknak.

\section{köszöNetwYILvánítís}

A publikáció elkészítését a „GINOP-2.3.2-15-2016-00062 Életminőség fejlesztése Kelet-Magyarországon: Táplálkozás-, teljesítménybiológiai és biotechnológiai experimentális kutatások és eszközfejlesztések a humán megbetegedések megelőzésére és kezelésére" projekt támogatta.
Tudományegyetem Közgazdaságtudományi Kar (PTE KTK), (2018) pp. 248-259. 12 p.

http://corporate.cms-horwathhtl.com/wp-content/ uploads/sites/2/2015/12/Tourism-Mega-Trends4.pdf Letöltve: 2020. október 4.

Juni, O. (2015): How to get Millennials to join your Hotel Loyalty Program. http://hospitality.cvent.com/ blog/junvi-ola/how-to-get-millennials-to-join-your-hotel-loyalty-program Letöltve: 2016. február 15.

Kiss, V. (2006): Kultúra és Közösség: A hunédzser: A modern kapitalizmus legitimációs fordulata és a fiatalok ideológiái

Michalkó, G. (2011): Turisztikai termékvezetés és fejlesztés, Pécsi Tudományegyetem

Mundruczóné, G. - Stone, G. (2010): A turisztikai fejlesztések állami támogatása. Budapest: Állami Számvevőszék Kutató Intézet

Pál, E. - Törőcsik M. (2013): A Z generációról. TÁ-
MOP-4.2.3-12/1/KONV-2012-0016, Tudománykommunikáció a Z generációnak. Pécsi Tudományegyetem, Pécs ft.

Pernyéz, I. (2003): Turizmus. Miskolc: Perfekt Kiadó

Puczkó, L. - Rácz, T. (2002): A turizmus hatásai. Budapest: Aula Kiadó Kft. 56. o.

Sőrés, A. (2013): Cognitive dimensions of subjective quality of life in Hajdú-Bihar County. APSTRACT - APPLIED STUDIES IN AGRIBUSINESS AND COMMERCE 7 4-5 pp. 131-136., 6 p. (2013)

Tóth, K. (2020): Mit akar az utazó? Budapesti Metropolitan Egyetem. Szakdolgozat. 56-57. o.

Tourism megatrend: http://29b8je4dgl4v2ndf9h4bmut9.wpengine.netdna-cdn.com/files/2015/12/Tourism-Mega-Trends4.pdf. Letöltés: 2016. 10. 10

Tütünkov, J. (2108): A Közvetítő szektor szerepe az Európai Unió turizmusában. Doktori disszertáció, Pécsi Tudományegyetem. 